Western North American Naturalist 69(2), (C) 2009, pp. 267-271

\title{
CAPTURE LOCATIONS OF TWO ENDANGERED RODENTS DURING A 1902 EXPLORATION OF THE SACRAMENTO MOUNTAINS, NEW MEXICO
}

\author{
Jennifer K. Frey ${ }^{1}$, Robert D. Fisher², Suzanne C. Peurach ${ }^{2}$
}

\begin{abstract}
We investigated localities from which Eutamias atristriatus Bailey, 1913 (= Tamias minimus atristriatus) and Zapus luteus Miller, 1911 (= Zapus hudsonius luteus) were collected during a 1902 survey in the Sacramento Mountains, New Mexico, by the United States Biological Survey. The locality from which the holotype of Eutamias atristriatus was collected is restricted to James Canyon rather than the Rio Peñasco. Locality records indicate that the historical distribution of Zapus hudsonius luteus and its obligate wetland habitat were broader than currently realized.
\end{abstract}

Key words: Tamias minimus atristriatus, Zapus hudsonius luteus, Peñasco least chipmunk, New Mexico meadow jumping mouse, distribution, New Mexico, Sacramento Mountains, type location, conservation.

During 5-16 September 1902 Vernon Bailey of the United States Biological Survey conducted one of the first biological explorations of the Sacramento Mountains, a large isolated mountain range in Lincoln and Otero counties in southern New Mexico. Results of that investigation provide important information on historical conditions of the region and a baseline for evaluating subsequent changes in distribution and abundance of the flora and fauna. Several species of mammals documented during that survey are now likely extirpated in the Sacramento Mountains, including the gray wolf (Canis lupus), thirteen-lined ground squirrel (Spermophilus tridecemlineatus), and black-tailed prairie dog (Cynomys ludovicianus; J.K. Frey personal observation). In addition, the endemic Peñasco least chipmunk (Tamias minimus atristriatus [Bailey, 1913]) and the New Mexico meadow jumping mouse (Zapus hudsonius luteus Miller, 1911) are listed as endangered in New Mexico (New Mexico Administrative Code 19.33.6); Z. h. luteus also recently was listed as a candidate for U.S. Endangered Species Act protection $(72 \mathrm{Fed}$. Reg. 69036 [Dec. 6, 2007]). Knowledge about historical capture locations of imperiled species is of critical importance for conservation because it provides a baseline for understanding the species' historical distribution and ecological associations, it allows for determination of subsequent changes in distribution and habitat, and it may allow for inferences about causes of the species' decline. In the case of T. m. atristriatus, accurate knowledge about collection locations is of special importance because the taxon was described based on the series of specimens collected during the survey. Therefore, the purpose of this paper is to identify more precisely the 1902 collection localities of T. m. atristriatus and Z. h. luteus in the Sacramento Mountains and to emend the type locality of T. m. atristriatus.

Bailey (1913:129-130) described Eutamias atristriatus on the basis of 10 specimens collected 6-7 September 1902 by himself and Ned Hollister in Otero County "along Penasco Creek at various points from 6 to 12 miles east of Cloudcroft and from 7000 to 8000 feet altitude, in the yellow pine zone." The holotype (United States National Museum [USNM] catalog number 119028) was reported as collected from "Sacramento Mountains, New Mexico, on Penasco Creek 12 miles east of Cloudcroft, alt. 7400 feet." Howell (1922) referred atristriatus to a subspecies of least chipmunk (= Tamias minimus atristriatus). Consequently, most subsequent treatments reported the type series as being collected along the Rio Peñasco, which is the major perennial river on the eastern slope of the Sacramento Mountains (e.g., Howell 1929, Bailey 1931, Poole and Schantz 1942, Hall 1981, Frey 1996). In contrast, locality data from specimen labels of the type series, including the holotype, do not specifically mention the Rio Peñasco (Table 1). Rather,

${ }^{1}$ Frey Biological Research, Box 294, Radium Springs, NM 88054. E-mail: frey_b_r@fastwave.biz

${ }^{2}$ USGS Patuxent Wildlife Research Center, National Museum of Natural History, Washington, DC 20013-7012. 
TABLE 1. Data from specimen tags of Tamias minimus atristriatus and Zapus hudsonius luteus collected during a 1902 expedition to the Sacramento Mountains, Otero County, New Mexico.

\begin{tabular}{|c|c|c|c|c|c|}
\hline $\begin{array}{l}\text { Species and } \\
\text { catalog number }\end{array}$ & Date & Locationa $^{a}$ & Collector & $\begin{array}{l}\text { Field } \\
\text { number }\end{array}$ & Remarks \\
\hline \multicolumn{6}{|c|}{ Tamias minimus atristriatus } \\
\hline 118821 & 6 Sep 2002 & "Penasco," "Upper Penasco" & N. Hollister & 129 & \\
\hline 118822 & 6 Sep 2002 & "Penasco," "Upper Penasco" & N. Hollister & 130 & \\
\hline 118823 & 6 Sep 2002 & "Cloudcroft," "12 mi. East" & N. Hollister & 131 & \\
\hline 118824 & 6 Sep 2002 & "Cloudcroft," "12 mi. East" & N. Hollister & 132 & \\
\hline 118825 & 6 Sep 2002 & "Cloudcroft," "12 mi. East" & N. Hollister & 133 & \\
\hline 118826 & 6 Sep 2002 & "Cloudcroft," "12 mi. East" & N. Hollister & 134 & \\
\hline 118832 & 7 Sep 2002 & "Cloudcroft," "6 mi. East" & N. Hollister & 144 & \\
\hline 118833 & 7 Sep 2002 & "Cloudcroft," "6 mi. East" & N. Hollister & 145 & \\
\hline 119028 & 6 Sep 2002 & "Cloudcroft," "12 mi. East 7400 feet" & V. Bailey & 7953 & holotyp \\
\hline 119029 & 6 Sep 2002 & "Cloudcroft," "12 mi. E. at 7400 feet" & V. Bailey & 7954 & \\
\hline \multicolumn{6}{|c|}{ Zapus hudsonius luteus } \\
\hline 118798 & 10 Sep 2002 & "Cloudcroft," "10 mi. N.E." & N. Hollister & 161 & \\
\hline 119032 & 7 Sep 2002 & "Cloudcroft," "12 mi. E. at 7500 feet" & V. Bailey & 7956 & \\
\hline 119033 & 7 Sep 2002 & "Cloudcroft," "12 mi. E. at 7500 feet" & V. Bailey & 7957 & \\
\hline
\end{tabular}

atocality data are reported as direct quotes from specimen tags. For each specimen the first quote is taken from the front of the tag and the second quote is taken from the back of the tag.

specimen label information indicates that the series was collected from 3 locations, including "Penasco, Upper Penasco", and "6 mi. East" and "12 mi. East" of Cloudcroft (Table 1). Conley (1970) reported the specimens to have been taken from James Canyon, but did not provide a justification for that interpretation; this was later reiterated by Findley et al. (1975).

In order to determine the collection locations, we examined Bailey's field journal, archived in the Division of Mammals, USNM. We noted itinerary information and mapped potential travel routes using a 1948 reprint of a 1914 edition of a 1:250,000 scale map of Lincoln National Forest (Fig. 1). In Bailey's journal, mileages were reported as distances traveled via road. Consequently, we correspondingly mapped potential routes via mapped roads. Further, we report the information using United States customary units $(\mathrm{mi}=$ miles, $\mathrm{ft}$ $=$ feet) rather than metric in order to more precisely relate the data from the field journal and historical map.

Specimens were collected as the party traveled by horse through the mountains and at nightly camps. The party entered the mountains from the southeast, reaching Weed on 5 September. On 6 September, Bailey wrote "From our camp a mile below Weed we followed down the valley of the Ahuachee Creek [= Agua Chiquita Creek] 5 or 6 miles [and] then over the ridges and down Hunter Hill to the Penasco which we struck 20 miles below Cloud- croft. Then followed up James Canyon to within 12 miles of Cloudcroft and camped. Came about 20 miles." In tracing this route on the 1914 map, one finds that the party first encountered the Rio Peñasco at the community of Upper Peñasco, now called Mayhill (Julyan 1998). The first 2 chipmunks of the series were collected at this location (Table 1). Locality information on the specimen labels included "Penasco," which we interpret as referring to the Rio Peñasco that flows through the town (Table 1). No other specimens included "Penasco" as part of the locality description, suggesting that they were not collected along the Rio Peñasco itself.

According to Bailey's notes, during 6-8 September the party traveled from Upper Peñasco up James Canyon about $20 \mathrm{mi}$ to Cloudcroft, which is located near the crest of the mountains. Other lines of evidence support this as the route traveled. James Canyon was the most direct route between the 2 towns (ca. $18.5 \mathrm{mi}$ ), while routes along Cox Canyon (ca. $23.0 \mathrm{mi}$ ) or the Rio Peñasco (ca. $29.5 \mathrm{mi}$ ) were longer and situated more to the south (Fig. 1). On 7 September Bailey wrote, "Followed up an easy grade with good road [and] camped about a mile [and] half east of Cloudcroft. Aneroid at camp 7500, at night camp 8700. At about 5 miles east of Cloudcroft we struck the edge of Canadian zone on N.E. slopes at 8000 feet." Bailey's statement indicates that the party did not cross into a different drainage after leaving 


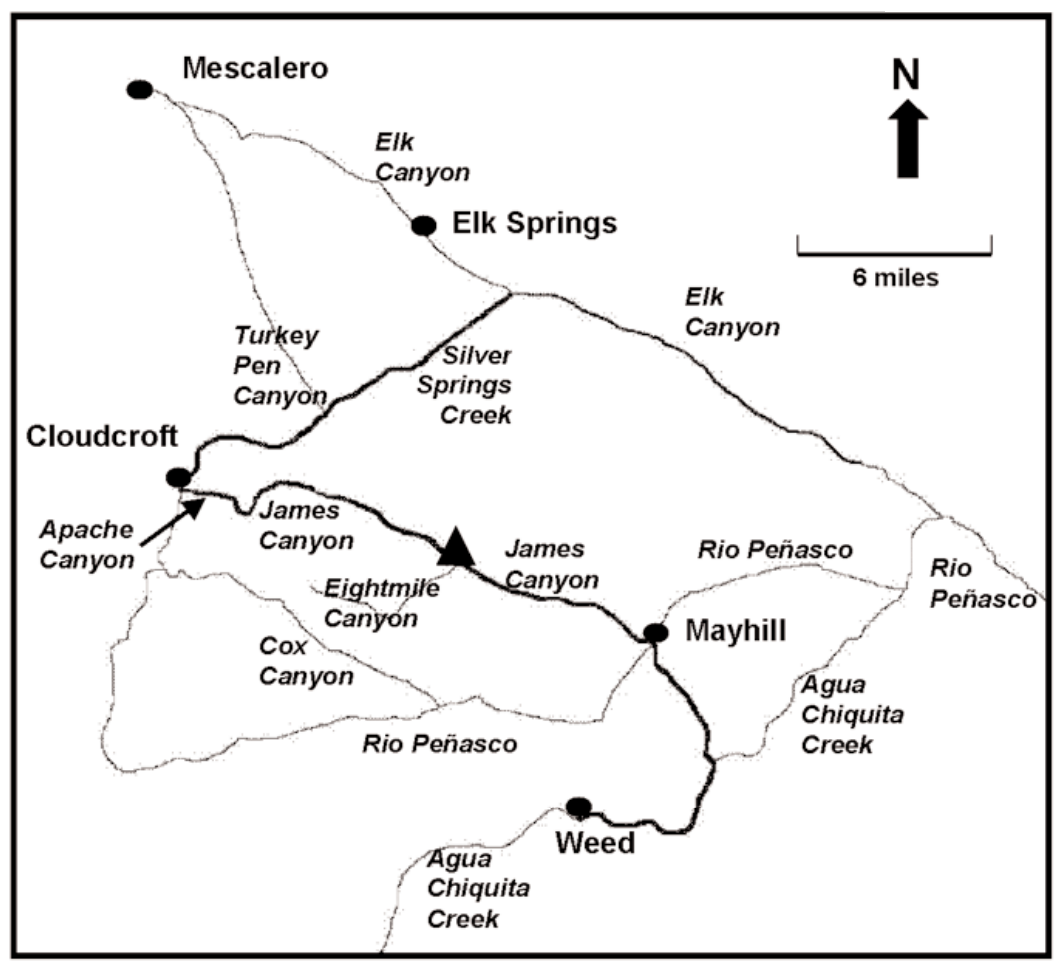

Fig. 1. Depiction of a 1914 map of Lincoln National Forest showing the presumed travel route (bold line) of Vernon Bailey during 5-10 September 1902 in the Sacramento Mountains, Otero County, New Mexico. Thin lines indicate roads, dots indicate modern place names, and names in italics are drainages. The triangle indicates the type locality of Eutamias atristriatus Bailey, 1913.

Mayhill. Further, elevations reported by Bailey at $12 \mathrm{mi}$ east of Cloudcroft (i.e., $7500 \mathrm{ft}$ ) and 5 mi east of Cloudcroft (i.e., $8000 \mathrm{ft}$ ), most closely match actual elevations in James Canyon. For example, the $8000-\mathrm{ft}$ contour is located ca. 5.75 mi east of Cloudcroft in James Canyon but ca. $8.0 \mathrm{mi}$ east of Cloudcroft in Cox Canyon. Finally, the 7 September camp 1.5 mi east of Cloudcroft was depicted on a hand-drawn map in Bailey's field journal to be located approximately in Apache Canyon, which is most easily accessed via James Canyon.

We conclude that the 8 specimens of T. $m$. atristriatus collected from 6 and $12 \mathrm{mi}$ east of Cloudcroft were collected in James Canyon rather than along the Rio Peñasco. This conclusion is supported by the fact that, while Bailey (1913) reported the type locality on "Penasco Creek," the original specimen tag does not include any reference to the Rio Peñasco (Table 1). The International Code of Zoological Nomenclature (Ride et al. 1999: Article 76) recommends correction of errors in statements of type localities. Therefore, we emend the type locality of E. atristriatus to "Sacramento Mountains, [Otero County,] New Mexico, on Penasco Creek [= James Canyon] 12 miles east of Cloudcroft [by road], alt. 7400 feet." This locality is in the vicinity of the junction of James Canyon and Eightmile Canyon.

The type series of $T$. $m$. atristriatus included specimens collected from 2 localities in James Canyon, as well as 1 locality along the Rio Peñasco at the mouth of James Canyon. In terms of conservation, these and other historical specimens of T. m. atristriatus contribute to understanding its historical distribution and current status. The last documentation of $T . m$. atristriatus in the Peñasco River watershed was in 1966 (Conley 1970), despite surveys for the species during 1981-1982 (Sullivan et al. no date), 2000 (Hope and Frey 2000), and 2007 (Frey and Boykin 2007). The taxon likely persists only above treeline on Sierra Blanca Peak at the northern end of the Sacramento Mountains, Lincoln County (Frey and Boykin 2007). 
Frey and Boykin (2007) concluded that extirpation of the chipmunk from the Peñasco River watershed was due to loss of mature ponderosa pine ecosystems.

Bailey also collected 2 specimens of $Z$. $h$. luteus on 7 September 1902 from the locality 12 mi east of Cloudcroft (Table 1), but described it as "from Penasco Creek 12 miles east of Cloudcroft in the Sacramento Mountains at 7,500 feet" (Bailey 1931:228). Thus, these records erroneously were considered to have been from the Rio Peñasco at the junction of Cox Canyon, which is about $13 \mathrm{mi}$ by modern road southeast of Cloudcroft (Frey 2005). Reallocation of these records to James Canyon has important conservation implications. Z. h. luteus is restricted to well-developed riparian habitats in close association with perennial water (Morrison 1992, Frey 2006, Frey and Malaney 2009). During field surveys conducted by one of us (JKF) in 2005 and 2007, James Canyon had no perennial water or riparian vegetation, and $Z$. h. luteus was extirpated from the canyon. Most of the length of the canyon, including the capture locality, was dominated by a large, dry erosion gully that was formed prior to 1957 . However, that $Z$. h. luteus formerly had a broad distribution within James Canyon is supported not only by Bailey's specimens, but also by a large series of specimens collected in 1978, 1979, and 1988 near the head of James Canyon at the mouth of Pumphouse Canyon, $3.2 \mathrm{mi}$ by road east of Cloudcroft (Hafner et al. 1981, Morrison 1992). Captures at this locality were at the Cloudcroft wastewater treatment facility and downstream seepage area (D. Hafner personal communication, Morrison in litt.). However, in 2005 and 2007 there was no riparian habitat at this site because the wastewater ponds had been developed and lined with plastic, and the numerous springs had been diverted and did not flow over the ground.

Bailey's survey party also documented $Z$. $h$. luteus on 10 September at a locality $10 \mathrm{mi}$ northeast of Cloudcroft (Table 1). Based on Bailey's field notes, the party left Cloudcroft on 8 September, crossed a ridge to the north of Cloudcroft, and then traveled down Silver Springs Canyon, where they camped about 4 $\mathrm{mi}$ from Cloudcroft at $8700 \mathrm{ft}$. On 9-10 September, Bailey continued down Silver Springs Canyon $3 \mathrm{mi}$ and then turned northwest up a side canyon, probably Turkey Pen Canyon, and camped near the canyon crest on the Mescalero Apache Reservation. On 10 September he rode to Mescalero and then returned to his camp in Turkey Pen Canyon, after which the party traveled via road toward Elk Springs. The party, which apparently included Hollister, who collected the specimen, camped about $6 \mathrm{mi}$ down Silver Springs Creek, while Bailey continued down Silver Springs Canyon and thence up Elk Canyon to Elk Springs, which was about $6 \mathrm{mi}$ beyond where the party camped. The location of Hollister's camp cannot be precisely determined but was on lower Silver Springs Creek in the vicinity of either Poison Spring Canyon or Indian Joe Canyon on the Mescalero Apache Reservation.

Bailey's hand-drawn map depicted continuous water from the head of Silver Springs Creek downstream to the junction with Elk Creek (= Elk Canyon) and thence downstream to beyond the eastern border of the Mescalero Apache Reservation. In contrast, during 2005 perennial water was present only along 2 short (ca. $2.1 \mathrm{mi}$ total) reaches of upper Silver Springs Creek above the Mescalero Apache Reservation. In the vicinity of Poison Spring and Indian Joe canyons, there was no surface water or riparian vegetation, and $Z$. h. luteus was certainly extirpated from that portion of Silver Springs Creek due to absence of suitable habitat.

We thank the New Mexico Department of Game and Fish, and Frey Biological Research for partial funding of this study. We thank T.C. Frey, A.F. O'Connell, Jr., J.P. Hubbard, and 3 anonymous reviewers for comments on previous versions of this paper.

\section{Literature Cited}

Bailey, V. 1913. Ten new mammals from New Mexico. Proceedings of the Biological Society of Washington 26:129-134.

1931 (1932). Mammals of New Mexico. North American Fauna 53:1-412.

Conley, W.H. 1970. Geographic variation in the least chipmunk, Eutamias minimus, in New Mexico and eastern Arizona. Journal of Mammalogy 51:695-702.

Findley, J.S., A.H. Harris, D.E. Wilson, and C. Jones. 1975. Mammals of New Mexico. University of New Mexico Press, Albuquerque. 360 pp.

FreY, J.K. 1996. Mammalian type localities in New Mexico. Museum of Southwestern Biology, Occasional Papers 7:1-21.

2005. Status assessment of montane populations of the New Mexico meadow jumping mouse (Zapus hudsonius luteus) in New Mexico. Final report submitted 
to New Mexico Department of Game and Fish, Conservation Services Division, Santa Fe, New Mexico. 74 pp. + appendixes.

2006. Status assessment of the New Mexico meadow jumping mouse (Zapus hudsonius luteus) in the Sangre de Cristo Mountains, New Mexico. Final report submitted to New Mexico Department of Game and Fish, Conservation Services Division, Santa Fe, New Mexico. 78 pp. + appendixes.

FREY, J.K., AND K. BoyKIn. 2007. Status assessment of the Peñasco least chipmunk (Tamias minimus atristriatus). Final report submitted to New Mexico Department of Game and Fish, Conservation Services Division, Santa Fe, New Mexico. 72 pp. + appendixes.

Frey, J.K., AND J.L. Malaney. 2009. Decline of the meadow jumping mouse (Zapus hudsonius luteus) in two mountain ranges in New Mexico. Southwestern Naturalist 54:31-44.

Hafner, D.J., K.E. Petersen, and T.L. Yates. 1981. Evolutionary relationships of jumping mice (Genus Zapus) of the southwestern United States. Journal of Mammalogy 62:501-512.

HaLl, E.R. 1981. The mammals of North America. Volume 1. 2nd edition. John Wiley \& Sons, New York. xviii $+600+90$ pp.

Hope, A.G., AND J.K. Frey. 2000. Survey for the Peñasco least chipmunk (Tamias minimus atristriatus) in the Lincoln National Forest with notes on rodent community assemblages. Final report submitted to Lincoln National Forest, Alamogordo, New Mexico. 48 pp.

HowelL, A.H. 1922. Diagnoses of seven new chipmunks of the genus Eutamias, with a list of the American species. Journal of Mammalogy 3:178-185.
1929. Revision of the American chipmunks (genera Tamias and Eutamias). North American Fauna 52:1-157.

Julyan, R. 1998. The place names of New Mexico. University of New Mexico Press, Albuquerque. 385 pp.

Morrison, J.L. 1992. Persistence of the meadow jumping mouse, Zapus hudsonius luteus, in New Mexico. Southwestern Naturalist 37:308-311.

Poole, A.J., And V.S. Schantz. 1942. Catalog of the type specimens of mammals in the United States National Museum, including the Biological Surveys Collection. United States National Museum, Bulletin 178:1-705.

Ride, W.D.L., H.G. Cogger, C. Dupuis, O. Kraus, A. Minelli, F.C. Thompson, and P.K. TubBs. 1999. International Code of Zoological Nomenclature. 4th edition. International Trust for Zoological Nomenclature, London. xxix +306 pp.

Sullivan, R.M., K.E. Petersen, and T.L. Yates. No date. Systematic status of the Peñasco chipmunk (Eutamias minimus atristriatus), with comments on the relationships between allopatric populations of least chipmunks in New Mexico and adjacent states. Final report submitted to the Endangered Species Program, New Mexico Department of Game and Fish, Santa Fe. $32+38$ pp.

Received 22 May 2008 Accepted 15 January 2009 